\title{
Securitization of Executory Future Flows as Bankruptcy-Remote True Sales
}

\author{
Thomas J. Gordon $\dagger$
}

Asset-backed securitization transactions have become a widely favored method of corporate finance. ${ }^{1}$ Companies securitize everything from the mundane accounts receivable, credit card receivables, and loan receivables, to the more exotic music royalties, taxicab medallions, ${ }^{4}$ and unpaid real estate taxes. ${ }^{5}$ While there are many reasons to securitize, the ability to eliminate bankruptcy risk to the creditor ranks as one of the most prominent.

In a regular unsecured lending arrangement, one of the primary risks the unsecured lender faces is that the borrower will go bankrupt and the lender will have a subordinate claim ${ }^{8}$ over the remaining assets in the borrower's bankruptcy estate. Even in a regular secured lending arrangement, the lender risks enduring a lengthy and costly bankruptcy process before being able to claim possession of collateral.' These risks can be substantially eliminated by a securitization that is structured through a special purpose vehicle ("SPV") to create

$\dagger$ B.A.1998, Yale University; J.D. Candidate 2001, The University of Chicago.

1 See Lois R. Lupica, Asset Securitization: The Unsecured Creditor's Perspective, 76 Tex L Rev 595, 601-03 (1998) (listing cash flows that have been securitized, including mortgages, auto loans, credit card receivables, hotel receivables, taxi cab medallions, health care receivables, and government contract receivables); Lynn M. LoPucki, The Death of Liability, 106 Yale L J 1, 24 (1996) ("Asset securitization is by far the most rapidly growing segment of the U.S. credit markets.").

2 LoPucki, 106 Yale L J at 25 (cited in note 1).

3 See Jennifer Burke Sylva, Comment, Bowie Bonds Sold for Far More Than a Song: The Securitization of Intellectual Property as a Super-Charged Vehicle for High Technology Financing, 15 Santa Clara Computer \& High Tech L J 195, 200-06 (1999) (discussing how performer David Bowie issued bonds backed by his future music royalties).

4 Lupica, 76 Tex L Rev at 602 (cited in note 1).

5 Id.

6 See id at 605 (listing benefits such as "improving liquidity, increasing diversification of funding sources, lowering the effective interest rate, improving risk management, and achieving accounting-related advantages").

7 Id at 648 ("[I]t is the transaction's bankruptcy-remote feature that has attracted [1996's] market to invest over one hundred billion dollars in asset-backed securities.").

8 With a subordinate claim, the unsecured creditor is only entitled to the money remaining in the bankruptcy estate after the secured creditors' claims are satisfied in full. See 11 USC $\S \S 506-07$ (1994).

911 USC $\$ 362(a)(3)$ (1994) provides that any attempt by a creditor to gain possession of collateral is stayed during the bankruptcy proceeding. 
a bankruptcy-remote true sale. ${ }^{10}$ This type of securitization treats a company's asset-backed capital financing as an outright sale of assets rather than a secured loan." In effect, a lender is no longer a true creditor holding a security interest in the company's securitized assets. Instead, the lender becomes a property owner of these assets.

By structuring a securitization as a true sale, the securitized assets will not be included in the company's bankruptcy estate. As a result, the bankruptcy risk that was present in the regular unsecured and secured lending arrangements is not present in a true sale securitization. Knowing that their investments will be "remote" from the company's potential bankruptcy proceedings, investors are willing to pay a higher price for securitized assets than they will for an unsecured debt obligation, all else being equal. In other words, securitizations allow companies to raise capital at a lower cost than they can through unsecured loans. For example, a company that cannot borrow unsecured at investment-grade interest rates may now be able to raise capital at those rates through securitization. ${ }^{13}$ Likewise, a company that already may borrow at investment-grade rates will now be able to raise capital at even lower.rates. ${ }^{14}$.

Such financing advantages have led companies to continue searching for more and more items to securitize. Securitization of executory future flows seems to be the next logical step. ${ }^{15}$ Executory future flows consist of the future revenue stream of an asset. ${ }^{16}$ Executory future flows are not assets; they are cash flows dependent on some

10 Steven L. Schwarcz, The Alchemy of Asset Securitization, 1 Stan J L, Bus \& Fin 133, 13536 (1994) ("Bankruptcy remote in this context means that the SPV is unlikely to be adversely affected by a bankruptcy of the [debtor]."). By structuring a securitization through a bankruptcyremote SPV, the debtor ensures that the SPV will not become part of the debtor's estate if the debtor should enter into bankruptcy.

11 See Peter L. Mancini, Note, Bankruptcy and the UCC as Applied to Securitization: Characterizing a Mortgage Loan Transfer as a Sale or a Secured Loan, 73 BU L Rev 873, 886 (1993) ("If a court determines that the transfer ... was an outright sale, then the buyer of that loan [or other securitized asset]-by definition-retains all of the legal and equitable interests in the loan, and thus the court will not include the loan in the seller's [bankruptcy] estate.").

12 Once the assets are sold in a securitization, they are no longer "legal or equitable interests of the debtor," thus excluding them from the debtor's bankruptcy estate. See 11 USC $\S 541$ (a)(1) (1994).

13 See Schwarcz, 1 Stan J L, Bus \& Fin at 137 (cited in note 10) (describing how an SPV's bankruptcy remoteness can give a company financing power similar to an investment-grade credit rating).

14 See id.

15 See Richard Gugliada, New Developments in Securitization 1998: Structured Finance Ratings Asset-Backed Securities New Assets 1998, 781 PLI/Comm 511, 611-14 (1998) (citing the fact that Standard \& Poor's expects future flow transactions to increase, and offering a possible structure and list of legal concerns for future flow securitizations); Schwarcz, 1 Stan J L, Bus \& Fin at 152-53 (cited in note 10) (describing the possibilities for future flow securitizations as "nearly limitless" and listing several examples of possible future flows to securitize).

16 Gugliada, 781 PLI/Comm at 611 (cited in note 15) (defining future flow securitizations). 
event occurring in the future that creates an asset. ${ }^{17}$ Whether the event creating the asset will ever occur is uncertain; therefore, it is uncertain whether the executory future flows will ever be realized. It is true that assets such as receivables also represent future cash flows. The difference is that the event upon which the cash flows depend has already occurred. ${ }^{18}$ Executory future flows have yet to accrue on a company's balance sheet. One can characterize them as future receivables or future future cash flows.

A concrete example best serves to illustrate an executory future flow securitization. Suppose an oil company is seeking capital to finance the extraction of a newly discovered oil field. Its engineers are convinced that the field will produce $\$ 50$ million worth of oil. The company seeks a less expensive financing option than traditional debt financing, but at the same time does not want to issue equity in the oil field since it prefers to keep all of the profits for itself. The company decides to finance the extraction of oil from the field through a securitization of the future receivables it will generate from the sale of that oil. ${ }^{19}$ In order to attain cheaper financing, the company would like to structure the transaction as a bankruptcy-remote true sale. It wishes to transfer the rights to all revenues from the oil field to an SPV in exchange for cash. The SPV will then sell securities to investors backed by the revenues that will accrue from the future oil sales.

Several prominent future flow securitizations have already taken place using a similar structure. In 1997, musician David Bowie issued bonds backed by the future royalty income of his songs. In 1996, Twentieth Century Fox raised $\$ 1$ billion by securitizing future film revenues. ${ }^{21}$ Recently, a professional sports team announced its intention to finance a new arena by securitizing future ticket and concession sales revenue. The one feature all these executory future flow securitizations have in common is that although they are structured through SPVs, they would probably be considered secured loans rather than true sales.

17 See Black's Law Dictionary 570 (West 6th ed 1990) (defining executory as "depending upon a future performance or event").

18 While this difference may seem minute on its face, the question of when an asset is created is essential to the bankruptcy law analysis of securitizations. See Part II.A, especially text accompanying notes 75-77. See also 11 USC $\$ 541$ (a)(7).

19 See Gugliada, 781 PLI/Comm at 611, 613-14 (cited in note 15) (describing natural resource harvesting as a future flow that would benefit from securitization).

20 Sam Adler, David Bowie \$55 Million Haul: Using a Musician's Assets to Structure a Bond Offering, 13 Enter L \& Fin 1 (Aug 1997).

21 See James Surowiecki, Gold into Led, Wired 77 (Sept 1998) (discussing entertainmentbased, asset-backed securities); Sylva, Comment, 15 Santa Clara Computer \& High Tech L J at 208 (cited in note 3 ).

22 Sylva, Comment, 15 Santa Clara Computer \& High Tech L J at 208-09 (cited in note 3).

23 See id at 209 (discussing the fact that these executory future flow securitizations include 
For a variety of reasons, efforts to structure future flow securitizations as bankruptcy-remote true sales have proven unsuccessful. As a result, companies have been unable to take advantage of bankruptcyremote financing for executory future flows. This Comment sets out the difficulties in characterizing an executory future flow securitization as a true sale and suggests a particular legal framework that practitioners could use to structure executory future flow securitizations as bankruptcy-remote true sales.

Part I defines the process of securitization and provides an expanded description of the SPV's crucial role in making a securitization a bankruptcy-remote true sale. Part II discusses the current state of bankruptcy law as it concerns securitizations. Specifically, it addresses pending legislation that, if passed, will affect the legal status of assetbacked securitizations. It then seeks to predict how courts may treat executory future flow securitizations in light of the fact that this legislation would not apply to such transactions directly. Part III lays out the legal barriers to structuring an executory future flow securitization as a bankruptcy-remote true sale. Finally, Part IV proposes guidelines for structuring an executory future flow securitization such that a bankruptcy court would treat it as a true sale.

\section{SECURITIZATION: AN EXPANDED DEFINITION}

While there is no absolute definition of securitization, ${ }^{24}$ one author has appropriately defined asset-backed securitization as the "sale of equity or debt instruments, representing ownership interests in, or secured by, a segregated, income-producing asset or pool of assets, in a transaction structured to reduce or reallocate certain risks inherent in owning or lending against the underlying assets." ${ }^{25}$ The definition of an executory future flow securitization may be extrapolated from this definition by replacing all references to "asset" with "executory future flow." According to this definition, a securitization is quite similar to a corporate bond. Both financial instruments allow a company to receive cash up front in return for making structured payments to investors at later dates. The difference is that in a regular bond obligation the borrower makes its payment out of its general

"other assurances for investors including adequate credit enhancements that are designed to kick in if and when an income stream evaporates"). The credit enhancements qualify as recourse to the SPV and its investors that compensates for the risk that the executory future flows will never materialize. As Part III.A will illustrate, the presence of this high level of recourse will most likely cause courts to characterize these securitizations as secured loans rather than true sales.

24 See Joseph C. Schenker and Anthony J. Colletta, Asset Securitization: Evolution, Current Issues and New Frontiers, $69 \mathrm{Tex} L \operatorname{Rev} 1369,1373$ (1991) (attempting to define securitization).

25 Id at 1374-75. 
pool of assets. In a securitization, on the other hand, the SPV meets its obligation to investors solely out of a pool of specifically set-aside assets (or future flows). ${ }^{26}$ By purchasing securitized assets that are separated from the debtor's regular assets, SPVs and their investors receive assets that cannot be touched by creditors of the company in the event that it declares bankruptcy.

\section{A. The Structure of a Securitization}

Securitizations adhere to a specific structure in the hopes of creating bankruptcy remoteness for the securitized items. A company attempting to securitize its assets (or future flows), known as an "originator" or a "seller," must first decide which assets it seeks to securitize." A rational originator is advised to choose some of its highest quality assets for securitization. The discount rate ${ }^{31}$ at which an originator can raise capital in a securitization is determined by the quality ${ }^{32}$ of the securitized assets and their ability to be bankruptcy remote. In a regular corporate unsecured loan, the discount rate is determined by the originator's overall creditworthiness. ${ }^{33}$ The originator only benefits from securitization when it securitizes assets at a lower discount rate than it could obtain from an unsecured loan. Consequently, the originator should only securitize its high quality assets and should try its best to make the securitizations bankruptcy remote.

The originator's next step is to establish an SPV. The SPV must be a separate legal entity from the originator. ${ }^{34}$ The SPV purchases the assets that later will be securitized from the originator. ${ }^{35}$ Then the SPV

26 For the rest of Part I, I will refer to the items being securitized as "assets" in order to simplify matters. Even though they are not assets, executory future flows can be securitized using the same basic securitization structure described in this Part. In Part IV, I will propose a structure that adapts this securitization process to meet the special concerns of executory future flows.

27 Schwarcz, 1 Stan J L, Bus \& Fin at 135 (cited in note 10) (explaining the mechanics of securitization).

28 Id.

29 See Robert D. Aicher and William J. Fellerhoff, Characterization of a Transfer of Receivables As a Sale or a Secured Loan upon Bankruptcy of the Transferor, 65 Am Bankr L J 181, 186 (1991).

30 See Schwarcz, 1 Stan J L, Bus \& Fin at 135 (cited in note 10).

31 The discount rate refers to the percentage by which the nominal expected cash flow from a securitized asset exceeds the amount for which the originator can sell the assets in a securitization. The lower the discount rate, the cheaper it is for the originator to raise capital via securitization.

32 In this context, "quality" refers to the probability that an asset will realize predicted cash flows to the fullest extent and on schedule.

33 Lupica, 76 Tex L Rev at 613 (cited in note 1). Note that the discount rate in a securitization is analogous to an interest rate in an unsecured loan.

34 Schwarcz, 1 Stan J L, Bus \& Fin at 135 (cited in note 10).

35 See Michael J. Cohn, Note, Asset Securitization: How Remote is Bankruptcy Remote?, 26 Hofstra L Rev 929, 931 (1998) (describing the securitization process). 
issues securities backed by these assets to investors. ${ }^{36}$ Finally, the proceeds from the securities are used to pay off the purchase price of the assets from the originator. ${ }^{37}$

In order to entice the investors to purchase these securities, the SPV must obtain a favorable credit rating ${ }^{33}$ from a rating agency on the assets. ${ }^{39}$ The credit rating standardizes and quantifies the securities' risks, allowing an investor to compare the risks of the SPV's securities versus other possible investments. ${ }^{40}$ Also, the credit rating certifies the quality of the securitized assets. A high credit rating allows the SPV to issue securities at a lower interest rate, thus allowing it to reserve a smaller amount of cash for repaying the debt. As a result, the SPV pays the originator a higher purchase price for its assets; by definition, this brings about a lower discount rate to the originator. ${ }^{41}$ Ultimately, it is the lower discount rate that makes securitizations an attractive financing option.

\section{B. The Purpose of the SPV}

The SPV serves three purposes. ${ }^{42}$ First, it is a pass-through ${ }^{43}$ entity that allows an originator's unique and illiquid assets to be transformed into standardized and liquid securities that may be sold to investors. ${ }^{44}$ Second, the SPV serves to protect its own investors-the investors in the securitized assets-from the SPV going bankrupt. ${ }^{45}$ Third, the SPV protects the securitized assets from third party claims, especially those

36 Id.

37 Schwarcz, 1 Stan J L, Bus \& Fin at 135 (cited in note 10). Presumably, the SPV could also borrow money to purchase the assets in full before selling the securities. When the securities are finally sold, the SPV then would use the proceeds from the securities to pay off the loan.

38 One commentator describes credit ratings as follows:

Credit ratings reflect the likelihood that investors will be repaid their [initial] investment, plus interest, on time and on the terms described in the transaction's offering documents, and provide investors with a means to compare a variety of investment products. The lower a security is rated, the higher risk it is deemed to be and thus the higher return paid. As such, lower rated securities result in more expensive funding for their issuers.

Lupica, 76 Tex L Rev at 611 (cited in note 1).

39 See Schwarcz, I Stan J L, Bus \& Fin at 136 (cited in note 10).

40 Id at 136-37.

41 Id at 136.

42 See Tamar Frankel, Securitization: The Conflict between Personal and Market Law (Contract and Property), 18 Ann Rev Bank L 197, 211 (1999) (describing the three main purposes of establishing an SPV).

43 Lupica, 76 Tex L Rev at 600 (cited in note 1), differentiates between "pay-through" SPVs and "pass-through" SPVs. While the SPVs discussed in this Comment are technically "paythrough" SPVs under Lupica's dichotomy, for the purposes of this Comment the term "passthrough" merely means that the SPV serves as an intermediary between the originator and the investors.

44 Frankel, 18 Ann Rev Bank L at 211 (cited in note 42).

45 Id at 211-12. For a discussion of the SPV as a bankruptcy-remote entity in and of itself, see Part I.B.2. 
of the originator's creditors. ${ }^{45}$ Each of these purposes will be examined in turn.

1. SPV as a pass-through to create liquidity.

In this context, an SPV acts as a pass-through entity in the sense that the originator's assets must travel through the SPV in order for the originator to raise capital from investors. ${ }^{47}$ Conceivably, an originator could directly issue securities that are backed only by a specific pool of its assets (a "direct sale"). But such securities would be unconventional debt instruments. Investors would encounter difficulties when trying to value them. Investors are familiar with traditional corporate debt instruments, like corporate bonds and notes, which are backed by the entirety of a company's assets. They know how to buy, sell, trade, rate, and value these instruments since they encounter many every day. With direct sale securities, an investor would incur high transaction $\operatorname{costs}^{48}$ in determining their value. These transaction costs make direct sale securities effectively worth less than the comparable conventional debt instruments even though they are backed by the same assets. Securities whose values decrease solely because of the transaction costs associated with them are known as "illiquid" securities. ${ }^{49}$ One can therefore characterize the direct sale securities as having less liquidity than traditional debt instruments.

The SPV solves the liquidity problem by transforming direct sale securities into conventional debt instruments. Instead of selling its assets directly, the originator sells its assets (to be securitized) to the SPV. The SPV then issues securities backed by its general pool of assets. The SPV's general pool of assets is comprised solely of the assets bought from the originator. Consequently, the SPV is effectively issuing securities backed by only a selected portion of the originator's assets, but in the form of a conventional corporate bond. By passing assets through an SPV, the originator solves its liquidity problem.

46 Id at 211.

47 In the securitization context, the term "pass-through entity" does not refer to any form of taxation or tax benefits whatsoever.

48 A transaction cost is the incidental cost incurred when one enters into an economic transaction. It is independent of the economic values of the goods or services being exchanged. For an extensive discussion of transaction costs, see R.H. Coase, The Problem of Social Cost, $3 \mathrm{~J}$ L \& Econ 1 (1960).

49 Illiquid means lacking liquidity. See Black's Law Dictionary 931 (cited in note 17) (defining liquidity as "[t]he degree to which an asset can be acquired or disposed of without danger of intervening loss in nominal value").

50 See Cohn, Note, 26 Hofstra L Rev at 931 (cited in note 35) (describing methods to establish bankruptcy remoteness through securitization). 


\section{SPV as a bankruptcy-remote entity in and of itself.}

Investors in securitized assets face the risk that the SPV will declare bankruptcy. The entire process of making sure the securitized assets are remote from the originator's bankruptcy proceedings would be moot if the SPV itself went bankrupt and was unable to pay off its investors. In order to induce investors to purchase the SPV-issued securities, the SPV's corporate charter must be set up in a manner that makes bankruptcy nearly impossible.

First, the charter must limit the SPV's activities solely to purchasing the originator's assets and issuing securities backed by these assets. ${ }^{\text {s. }}$ Since the SPV exists only for these purposes, it is a special purpose vehicle. Limited to these special purposes, there should be no situation outside of the securitization that could cause the SPV to go bankrupt. The SPV engages in no other activities that would cause it to take on liabilities. The only remaining risk of bankruptcy is if the receivables held by the SPV go uncollected. Of course, the SPV's investors agree to bear this risk, which is represented to them in the form of the credit rating.

Second, the charter must contain a provision stating that the SPV's board of directors needs to have at least one independent director. ${ }^{33}$ An independent director acts as a check on the SPV's board (which is otherwise chosen by the originator) to ensure the board acts in the best interests of the SPV's investors. ${ }^{34}$ Since the investors are concerned with the bankruptcy-remote status of the SPV being compromised, the charter must provide that the independent director(s) has veto power over board actions that jeopardize bankruptcy remoteness. These actions include the ability to file a voluntary bankruptcy or insolvency petition; the ability to dissolve, liquidate, consolidate, merge, or sell substantially all of the SPV's assets; the ability to engage in any business activity besides the specified special purpose; and the ability to amend the SPV's organizational documents.

Finally, the charter must provide that the SPV is prohibited from merging with any entity that will not adopt the same bankruptcy-

51 Id at 933. If the purchase of assets is structured so that the SPV also has to borrow money to make the purchase, the charter can contain a provision allowing the SPV to borrow only for this specific purpose.

52 See notes 38-41 and accompanying text.

53 See Malcolm S. Dorris and Edward J. O'Connell, New Developments in Securitization: Problem Cases in Bankruptcy, 732 PLI/Comm 99, 105-06 (1995) (suggesting ways to ensure that an SPV is "extremely unlikely" to be involved in a bankruptcy). See also Sylva, Comment, 15 Santa Clara Computer \& High Tech L J at 218-19 (cited in note 3); Cohn, Note, 26 Hofstra L Rev at 932 (cited in note 35 ).

54 Cohn, Note, 26 Hofstra L Rev at 932 (cited in note 35).

55 Sylva, Comment, 15 Santa Clara Computer \& High Tech L J at 218-19 (cited in note 3); Dorris and O'Connell, 732 PLI/Comm at 105-06 (cited in note 53). 
avoiding provisions. This clause protects the SPV from losing its bankruptcy-remote status. More importantly, it leaves open the possibility that an originator could merge its SPV into that of another originator. This merger of SPVs creates a "multiseller securitization conduit" ("MSC"). ${ }^{57}$ An MSC is advantageous since its multioriginator nature reduces the likelihood that it will be considered the alter ego of

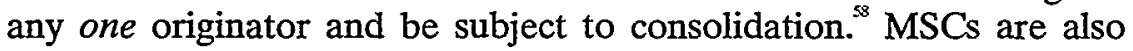
more attractive to investors since they are basically mutual funds, and therefore serve to diversify investors' portfolios.

\section{SPV as a protection from third party creditors.}

This section illustrates the SPV's most important function: its ability to remove assets from the originator's bankruptcy estate. The bankruptcy code provides that the originator's (debtor's) bankruptcy estate includes "all legal or equitable interests of the debtor in property as of the commencement of the case.", By definition, a true sale of property extinguishes all of the seller's legal and equitable interests in the property. Consequently, any property transferred from the originator to an SPV in the form of a true sale is not included in the originator's bankruptcy estate. The property is "bankruptcy remote."

There are two distinct situations that could cause courts to consolidate the SPV's assets into the bankruptcy estate of the originator, thereby thwarting an originator's attempt at bankruptcy remoteness. These risks will be termed the separate entity risk and the characterization risk. If a securitization falls victim to either of these risks, the SPV (and its investors/creditors) must compete with all of the originator's creditors during the bankruptcy proceeding for the originator's

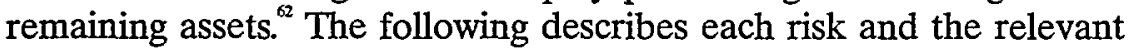
law that has shaped it.

a) Separate entity risk. If a bankruptcy court determines that the SPV is not a substantially separate legal entity from the originator, it may consolidate the SPV's assets with the originator's in the originator's bankruptcy estate. A key issue is whether the SPV is an "alter

\footnotetext{
56 See Sylva, Comment, 15 Santa Clara Computer \& High Tech L J at 218 (cited in note 3); Dorris and O'Connell, 732 PLI/Comm at 105-06 (cited in note 53).

57 Schwarcz, 1 Stan J L, Bus \& Fin at 140 (cited in note 10).

58 See Part I.B.3.a.

5911 USC \$ 541(a)(1).

60 See Mancini, Note, $73 \mathrm{BU}$ L Rev at 886 (cited in note 11) (discussing the effect of the true sale of an asset in the context of mortgage loan transfers).

61 Schwarcz, 1 Stan J L, Bus \& Fin at 135 (cited in note 10) ("Bankruptcy remote in this context means that the SPV [meaning the SPV's property] is unlikely to be adversely affected by a bankruptcy of the originator.").

62 See 11 USC \& 544(a) (1994).
} 
ego" of the originator. ${ }^{63}$ In determining alter ego status, courts inquire into the relationship between two entities to determine whether they truly are acting at arms' length.

Traditionally, courts have ordered alter ego consolidations if two conditions are satisfied. First, alter ego status must be established. Second, the originator's creditors must show that they relied to their detriment upon a belief that the originator and SPV were not separate legal entities. ${ }^{65} \mathrm{~A}$ bankruptcy court will only invoke consolidation to protect creditors if they have suffered a substantial harm.

Despite the significant burden of proof needed to demonstrate alter ego status, the originator must still take steps to ensure that the SPV functions as an independent legal entity. The Committee on Bankruptcy and Corporate Reorganization of the Association of the Bar of the City of New York has proposed a comprehensive list of factors to help determine whether an SPV is a substantially separate legal entity. ${ }^{6}$ These factors, such as compliance with corporate formali-

63 See In re New Center Hospital, 187 Bankr 560, 568-69 (Bankr E D Mich 1995) (describing the determination of alter ego status as "critical" to the analysis of consolidation in bankruptcy).

64 Id at 569, citing In re Augie/Restivo Baking Co Ltd, 860 F2d 515 (2d Cir 1988). In New Center Hospital, the court enunciated a seven-part test for determining alter ego status: “(1) presence or absence of consolidated business or financial records; (2) unity of interest and ownership between the debtors; (3) the existence of parent and intercorporate guarantees on loans; (4) degree of difficulty in segregating and ascertaining separate assets and liabilities; (5) existence of transfers of assets without observance of corporate or other legal formalities; (6) commingling of assets and business functions; and (7) the profitability of consolidation at a single principal location." 187 Bankr at 569.

65 See Augie/Restivo, 860 F2d at 518 (Detrimental reliance can be shown by demonstrating that the creditors, in extending credit, did not rely on there being separate legal entities. Alternatively, it may be shown by demonstrating that the affairs of the two entities are "so entangled that consolidation will benefit all creditors"). See also In re American Way Service Corp, 229 Bankr 496, 527 (Bankr S D Fla 1999) (providing a recent example of a substantial consolidation under the "so entangled" standard).

66 See In re Snider Bros, Inc, 18 Bankr 230, 234 (Bankr D Mass 1982) ("A review of the case law reveals that equity has provided the remedy of consolidation in those instances where it has been shown that the possibility of economic prejudice which would result from continued corporate separateness outweighed the minimal prejudice that consolidation would cause."). It is unclear how the proposed Bankruptcy Reform Act of 2000, which pertains to asset-backed securitizations, will, if enacted, affect this separate entity requirement. See note 69 and accompanying text. As Part II.A points out, the bill does not address the issue. One likely interpretation is that the new legislation does not require the SPV to be a separate legal entity in order for the assets to avoid consolidation. Another possible interpretation is that because alter ego consolidation is an equitable doctrine and the proposed legislation is silent on the issue, bankruptcy courts still have the power to consolidate alter ego SPVs when it would be equitable to do so.

67 The factors are as follows: (1) The SPV's compliance with its corporate formalities; (2) The separateness of SPV decisionmaking from that of the originator; (3) The separateness of SPV operations from those of the originator; (4) Whether the SPV has actual possession of the securitized assets; (5) The SPV's management of its liabilities; (6) The separateness from the originator of the SPV's offices; (7) The separateness from the originator of the SPV's financial statements; (8) The arms' length nature of the SPV's transactions with the originator and affiliates; (9) The extent of disclosure of the separateness of the SPV and its assets from the origina- 
ties, non-commingling of assets, and separate financial reporting, describe an SPV that has the necessary detachment to be able legitimately to engage in an arms' length transfer of assets with the originator. By following these guidelines, the SPV can serve as a successful vehicle to segregate securitized assets.

b) Characterization risk. Characterization risk is the risk that a bankruptcy court will view the originator's conveyance of assets to the SPV as a secured loan rather than as a true sale. Under this analysis, a court could hold that the SPV has not "purchased" the originator's assets, but rather has loaned money to the originator, secured by the securitized assets. As a result, the SPV becomes a creditor of the originator. If the originator declares bankruptcy, the SPV, and consequently the investors in SPV-issued securities, must compete with the rest of the originator's creditors for a share of the originator's estate.

The investors want to avoid this characterization risk. If courts characterize a securitization as a secured loan, then investors would have to endure the long time delays and repayment uncertainty associated with bankruptcy proceedings. To avoid this situation, originators must find a securitization structure that eliminates the characterization risk.

To structure a securitization to avoid characterization risk, a practitioner must be able accurately to predict when courts will invoke their powers to characterize securitizations as secured loans. When it pertains to executory future flow securitizations, this task is extremely difficult because of the evolving nature of the law. Part II analyzes the current state of bankruptcy law regarding asset-backed securitizations with an eye towards ascertaining how the law relates to executory future flow securitizations.

\section{THE CURRENT STATE OF BANKRUPTCY LAW}

The current state of bankruptcy law, as it pertains to asset-backed securitizations, is in flux due to the Bankruptcy Reform Act of 2000 ("Reform Act") ${ }^{69}$ now pending in Congress. Among its many provi-

tor; and (10) The separateness from the originator of the relationship between the SPV and third parties such as contracting parties, creditors, and certificate holders. The Committee on Bankruptcy and Corporate Reorganization of the Association of the Bar of the City of New York, Structured Financing Techniques, 50 Bus Law 527,559-60 (1995).

68 See Thomas E. Plank, The True Sale of Loans and the Role of Recourse, 14 Geo Mason U L Rev 287, 307-10 (1991), for a complete discussion of the technical bankruptcy rules that allow for the securitized assets to revert to the originator's bankruptcy estate in this securitizationas-secured-lending situation.

69 HR 833, 106th Cong, 1st Sess (Feb 24,1999), available online at <http://thomas.loc.gov> (visited July 23, 2000); S 625, 106th Cong, 1st Sess (Mar 16, 1999), available online at <http://thomas.loc.gov> (visited July 23, 2000). While the House bill and the Senate bill differ in other sections, Section 903 of each bill has identical provisions on asset-backed securitizations. 
sions, the Reform Act seeks to clarify how bankruptcy courts should address the issue of true sale characterization. If passed, it will provide clear legal boundaries for asset-backed securitizations. While the Reform Act does not extend to executory future flow securitizations, it does provide a source of encouragement to originators seeking to structure executory future flow securitizations as true sales.

\section{A. The Bankruptcy Reform Act of 2000}

Section 903 of the Reform Act is titled "Asset-Backed Securitizations." ${ }^{\text {70 }}$ If passed, it will amend Section 541 of the Bankruptcy Code," which sets out what is and is not included in a debtor's bankruptcy estate. Specifically, it will exclude from the bankruptcy estate "any eligible asset (or proceeds thereof), to the extent that such eligible asset was transferred by the debtor, before the date of commencement of the case, to an eligible entity in connection with an asset-backed securitization." ${ }^{n}$ Under this legislation, an asset-backed securitization will, with certainty, be considered a bankruptcy-remote true sale as long as the transaction fits within the statutory definition of asset-backed securitization.

The proposed Reform Act defines "asset-backed securitization" as "a transaction in which eligible assets transferred to an eligible entity are used as the source of payment on securities, the most senior of which are rated investment-grade by 1 or more nationally recognized securities rating organizations, issued by an issuer." ${ }^{\text {, }}$ This definition is basically equivalent to the definition of asset-backed securitization offered in Part I. ${ }^{4}$

The proposed Reform Act then goes on to define "eligible assets" as

financial assets (including interests therein and proceeds thereof), either fixed or revolving, including residential and commercial mortgage loans, consumer receivables, trade receivables, and lease receivables, that, by their terms, convert into cash within a finite time period, plus any rights or other assets de-

70 HR $833 \S 903$ (cited in note 69 ); $S 625 \S 903$ (cited in note 69 ).

7111 USC $\$ 541$.

72 HR $833 \S 903(5)$ (cited in note 69); $S 625 \$ 903$ (5) (cited in note 69).

73 HR $833 \S 903(\mathrm{e})(1)$ (cited in note 69); $\mathrm{S} 625$ \$ 903(e)(1) (cited in note 69).

74 The only real difference is the requirement of an investment-grade credit rating of the assets. In reality, however, this requirement only makes explicit in the definition what was already implicit. There was already a tacit requirement by investors that the assets have an investment-grade rating; otherwise, investors would not buy into securitizations. See notes 38-41 and accompanying text. 
signed to assure the servicing or timely distribution of proceeds to security holders. ${ }^{25}$

This definition appears broad, stating that virtually all types of assets (and proceeds thereof) may be securitized. However, it is clearly not intended to include executory future flows. As stated above, executory future flows are not assets; they are proceeds from assets that may be created in the future. ${ }^{76}$ As a result, executory future flows do not meet the "financial assets" requirement for "eligible assets." Also, executory future flows are distinct from the type of assets explicitly listed in the definition. The enumerated assets, such as mortgage loans and consumer receivables, are not executory because the events upon which their accrual depend have already occurred (namely the issuance of a mortgage loan and a sale of a good to a consumer, respectively). ${ }^{n}$ Furthermore, executory future flows do not "convert into cash within a finite time period." For example, an asset such as a mortgage loan has a strict monthly payment. As a result, it will convert into cash within a finite time-a month. In contrast, the executory future flows from a mortgage loan yet to be made do not convert into cash within a finite time period because it is uncertain as to when and if the loan will be made. If a loan is made tomorrow, it will convert into cash in a month and a day, but if it is made eleven months from now, it will not convert into cash for a year.

The Reform Act defines "eligible entity" as a "trust corporation, partnership, or other entity engaged exclusively in the business of acquiring and holding eligible assets, issuing securities backed by eligible assets, and taking actions ancillary thereto." ${ }^{\prime 3}$ This definition simply encompasses the traditional definition of an SPV, because an SPV is an entity whose exclusive function is to acquire securitized assets and issue securities backed by these assets.

Since the Reform Act will most likely not extend to executory future flow securitizations, there is still uncertainty as to how courts will treat these securitizations. One might interpret the passage of the Reform Act as demonstrating a congressional intent to encourage all

75 HR $833 \S 903(\mathrm{e})(2)(\mathrm{A})$ (cited in note 69); $\mathrm{S} 625$ \$903(e)(2)(A) (cited in note 69).

76 See notes $16-17$ and accompanying text.

$\pi$ See note 18 and accompanying text.

78 HR 833 \$ 903(e)(3)(B) (cited in note 69); S 625 \$903(e)(3)(B) (cited in note 69).

79 It is uncertain whether the proposed Act will require an SPV to be a separate legal entity from the originator. The Act is silent on this issue. There is a strong argument, however, that the separate entity requirement still exists. The debtor must "transfer" eligible assets to the eligible entity under proposed 11 USC $\$ 541(b)(5)$. HR $833 \$ 903$ (1) (cited in note 69); S 625 § 903(5) (cited in note 69). It seems implausible under the definition of "transfer" in 11 USC $\$ 101(54)$ (1994), which is "parting with property or with an interest," that the originator can truly "transfer" an asset to its alter ego. The asset would not "part" with the originator.

80 See notes 34-37 and accompanying text for a description of an SPV's function. 
true sale securitizations, including executory future flow securitizations, even though executory future flows are not explicitly mentioned in the Act. However, because of the unique legal questions surrounding executory future flow securicizations, which are discussed in Part III, and because executory future flow securitizations will not be covered explicitly by the text of the Reform Act, the more likely intepretation is that courts will give executory future flow securitizations a higher level of scrutiny than asset-backed securitizations. This interpretation is further supported by the fact that executory future flows are not mentioned in the legislative history of the Reform Act. And, as mentioned above, executory future flows are significantly different from financial assets to such an extent that they cannot be lumped into the "eligible assets" category of the Reform Act.

As a result, one must look beyond the Reform Act and its legislative history to predict how courts will treat executory future flow securitizations. One must look to case law. Since no case law has specifically dealt with executory future flow securitizations, the analysis must be done by analogy, and must ascertain how courts have traditionally considered transactions similar to executory future flow securitizations.

Part II.B analyzes how courts have traditionally scrutinized the true sale/secured loan issue for transactions similar to executory future flow securitizations to predict how future courts will scrutinize executory future flow securitizations. This analogous case law will inform courts' decisions under both current law and the Reform Act.

\section{B. The Case Law: True Sale Versus Secured Loan}

The application of bankruptcy case law to securitizations remains unclear, primarily because bankruptcy courts have never considered whether securitizations constitute true sales or secured loans. ${ }^{82}$ Practitioners must draw on the bankruptcy law of similar transactions, such as direct sales of accounts receivable, and analogize this to securitizations.

The secured loan/true sale issue was first illustrated by Major's Furniture Mart, Inc v Castle Credit Inc, ${ }^{\text {s4 }}$ a case where a furniture com-

81 See notes 75-77 and accompanying text.

82 See Christopher W. Frost, Asset Securitization and Corporate Risk Allocation, 72 Tulane L $\operatorname{Rev} 101,108$ (1997) (analyzing the doctrinal context of asset securitization). Courts have considered securitizations as they apply to other legal issues. See, for example, In re Kingston Square Associates, 214 Bankr 713, 714 (Bankr S D NY 1997) (considering securitizations in the context of whether to uphold bad faith involuntary bankruptcy petitions made by the SPV's creditors); In re Buckhead America Corp, 161 Bankr 11 (Bankr D Del 1993) (considering securitizations in the context of single entity risk).

83 See Frost, 72 Tulane L Rev at 110 (cited in note 82).

84602 F2d 538 (3d Cir 1979). 
pany transferred its accounts receivable to a finance company in exchange for cash. ${ }^{85}$ The Third Circuit stated that the Uniform Commercial Code "does not provide assistance in distinguishing between the character of such transactions. This determination, as to whether a particular assignment constitutes a sale or a transfer for security, is left to the courts for decision." Following this apparent delegation to the courts, the Third Circuit held that the furniture company did not engage in a true sale despite the company's characterization as such. The Third Circuit characterized the transaction as a secured loan because the furniture company guaranteed that the finance company would receive its payments regardless of the collectability of the receivables; this guarantee took the form of various types of security.

The Third Circuit offered bankruptcy courts some guidance in distinguishing a sale from a transfer for security, stating that they must look beyond the transacting parties' characterization of the transaction and instead ascertain whether the "true nature of the transaction [is] such that the legal rights and economic consequences of the agreement bear a greater similarity to a financing transaction or to a sale." Under the proposed Reform Act, this statement would no longer apply to asset-backed securitizations. Instead, asset-backed securitizations will be characterized as true sales if the originator simply states its intent to create a true sale, regardless of whether the underlying nature of the transaction is actually that of a true sale. This is by far the most radical departure the Reform Act makes from the current case law.

Since Major's Furniture Mart, courts have further developed the true sale/secured loan doctrine. They have looked to several factors in deciding the issue. The following factors are pertinent to this Comment.

1. The intent of the parties as evidenced by their writings.

Unsurprisingly, the first factor courts often consider in characterizing a transaction is the intent of the transacting parties. In determining the true intent of the parties, courts may look at parol evidence $^{\mathrm{pn}}$ in addition to the written agreements between the parties."

85 Id at 539.

86 Id at 543 .

87 Id at $545-46$.

88 Id at 544.

89 See HR $833 \$ 903(\mathrm{e})(5)$ (cited in note 69); $\mathrm{S} 625 \$ 903$ (e)(5) (cited in note 69). These sections state that an originator can create a true sale merely by "represent[ing] and warrant[ing] that eligible assets were sold."

90 "Oral or verbal evidence ... which is given by word of mouth." Black's Law Dictionary at 1117 (cited in note 17).

91 See In re Evergreen Valley Resort, Inc, 23 Bankr 659, 661 (Bankr D Me 1982) (holding 
"The court should examine the parties' conduct, practices, objectives, business activities, and relationships."' After examining the evidence, it is up to the court's discretion to determine the parties' true intent. In In re Evergreen Valley Resort, Inc, ${ }^{\text {s4 }}$ a bankruptcy court stated that "[i]t is clear that an assignment may operate to transfer a security interest, rather than absolute ownership, if it is intended to create a security interest.". ${ }^{\text {,s }}$ However, the converse of this statement, that an assignment may transfer absolute ownership if the parties intend it, is not true given the ruling in Major's Furniture Mart.

Nonetheless, the transacting parties' intent, though currently not sufficient to create a true sale, does seem to be a necessary requirement for a true sale. If the transacting parties do not intend a true sale, a court would be hard pressed to find any reason to characterize their transaction as such. The transacting parties would not benefit from this characterization against their wills, and neither would any third parties.

2. The absence of recourse against the originator.

Another factor courts consider is recourse. Recourse, in this context, is defined as the remedy the SPV has against the originator if the securitized receivables go into default. ${ }^{\circ}$ Recourse can take many forms, such as an originator's obligation to repurchase the defaulting receivables, ${ }^{\$ \%}$ an originator's cash-backed guarantee that the receivables will be collected, or the SPV's ability to withhold cash payment to the originator until the corresponding receivables are collected. ${ }^{100} \mathrm{~A}$

that a court "is not restricted to an examination of the written agreement").

92 Id. See also In re Lemons \& Associates, Inc, 67 Bankr 198, 209-10 (Bankr D Nev 1986). The court looked to brochures advertising the transaction as a "sale," in addition to the transaction agreement itself, to determine whether the parties intended a sale. Ultimately, the parties' intent was one of several factors that led the court to characterize the transaction as a true sale. Id.

93 See, for example, Lemons \& Associates, 67 Bankr at 209-10 (deciding the intent of the parties); Evergreen Valley, 23 Bankr at 661 (same).

9423 Bankr 659 (Bankr D Me 1982).

95 Id at 661.

96602 F2d at 546

97 If the Reform Act is passed, intent will be the only factor courts look at for asset-backed securitizations.

98 For a formal definition of recourse, see Black's Law Dictionary at 1275 (cited in note 17) (defining recourse as: "[t]he right of a holder of a negotiable instrument to recover against a party secondarily liable, e.g., prior endorser or guarantor.").

99 The Bankruptcy Reform Act of 2000 specifically allows a securitization to be a true sale even if the originator maintains a repurchase obligation. See HR $833 \S 903(\mathrm{e})(5)(B)$ (cited in note 69); $\mathrm{S} 625 \$ 903$ (e)(5)(B) (cited in note 69). Nonetheless, it is doubtful that a bankruptcy court will require the originator to fulfill its repurchase obligation once it files for bankruptcy because it is an executory contract subject to 11 USC § 365(a) (1994) (A debtor has the right to "assume or reject any executory contract" in bankruptcy.).

100 See Aicher and Fellerhoff, Characterization of a Transfer of Receivables, 65 Am Bankr L 
securitization transaction may be characterized as a true sale even if the SPV maintains some degree of recourse from the originator to cover the defaults of the assets purchased. ${ }^{101}$ Even if the SPV has "full recourse" ${ }^{\text {102 }}$ against the originator, the transaction can still be characterized as a true sale.

Nonetheless, the existence of significant recourse is the single greatest factor that leads courts to characterize transactions as secured loans. ${ }^{104}$ Courts have reasoned that a purchaser who maintains substantial recourse does not bear the risks of ownership. In Major's Furniture Mart, the Third Circuit held that a transaction where accounts receivable were (1) sold with a reserve from the purchase price held back by the buyer to cover uncollected accounts and (2) sold with a provision forcing the seller to buy back any delinquent accounts within sixty days resembled a secured loan more than a true sale. ${ }^{105}$ The purchaser bears none of the risks of ownership in this type of transaction, including the risk that the accounts are in default. For this reason, the court disregarded the parties' characterization of the transaction as a true sale, and instead characterized the transaction as a secured loan. ${ }^{106}$

In In re Woodson $\mathrm{Co}^{107}$ a seller of receivables paid the purchaser the value of receivables as they came due, whether or not they were actually collected. ${ }^{16}$ The court held that the transaction was a secured loan since the seller relieved the purchasers of "all risk of loss."109 Similarly, in In re S.O.A.W. Enterprises, Inc, ${ }^{110}$ the seller was obligated to "repurchase" the receivables sold to the purchaser if these receivables were in default, and was obligated to put up collateral against

$\mathrm{J}$ at 186 (cited in note 29) (analyzing the factors that affect a court's determination of whether a transaction is a sale or a loan).

101 See UCC \$ 9-502 cmt 4, 3B Uniform Laws Annotated (West 1992) ("[T] here may be a true sale of accounts or chattel paper although recourse exists.").

102 Full recourse is recourse equal to or exceeding the total amount of receivables purchased.

103 Major's Furniture Mart, Inc v Castle Credit Corp, Inc, 449 F Supp 538, 542-43 (E D Pa 1978), affd, 602 F2d 538 (3d Cir 1979) (rejecting contention that the existence of a full recourse provision "automatically transforms any sale of accounts into a transfer of a security interest").

104 See Major's Furniture Mart, 602 F2d at 540. See also In re Woodson Co, 813 F2d 266, 271-72 (9th Cir 1987) (characterizing investments in which the debtor relieved the investors of all risk of loss as not being sales); In re S.O.A.W. Enterprises, Inc, 32 Bankr 279, 283 (Bankr W D Tex 1983) (finding an agreement in which the debtor was absolutely obliged to repurchase the creditor's investment to consist of a normal debtor/creditor relationship and not a sale).

105602 F2d at $540,545-46$.

106 Id.

107813 F2d 266 (9th Cir 1987).

108 Id. See also In re Lendvest Mortgage, Inc, 119 Bankr 199, 200-01 (BAP 9th Cir 1990) (holding a transaction to be a loan and not a sale where the risk of loss is shifted from the investor to the debtor through a guarantee of repayment), affd, 42 F3d 1181 (9th Cir 1994).

109 Woodson Co, 813 F2d at 271.

11032 Bankr 279 (Bankr D Tex 1983). 
these defaults. ${ }^{\text {11 }}$ The court characterized this agreement as a secured loan.

In contrast, In re Golden Plan of California ${ }^{112}$ held that a contract for the purchase of assets, which was clearly marked "WITHOUT RECOURSE" and which in fact had no "contractual guarantee of repayment or compensation in case of foreclosure [upon the accounts receivable]," was a true sale. "While lack of recourse is not sufficient on its own to create a true sale, executory future flow securitization practitioners should pay close attention to this case. The lesson to be learned is that a securitization intended to be structured as a true sale should, if at all possible, contain a "no recourse" provision.

3. The right to a surplus of the securitized assets.

A securitization could be structured so that the purchase price that the SPV pays to the originator is discounted by the expected default rate on the receivables purchased. ${ }^{114}$ For example, the securitized assets may represent a present value of $\$ 100$, with a 10 percent default rate. The SPV, accounting for the expected default rate, would purchase the assets for $\$ 90$. A few months down the road when the assets' cash flows are realized, only a 5 percent default rate is realized. The SPV would realize a $\$ 95$ value on its $\$ 90$ purchase, representing a $\$ 5$ surplus.

It seems logical that if the SPV purchased the asset through a true sale, it would be allowed to keep this surplus as a benefit of ownership. If, on the other hand, the SPV made a secured loan to the originator; then the SPV would return the surplus, since the originator is only obligated to pay back the loan amount. Courts support this reasoning by holding that if the surplus is returned to the originator, "a security interest is indicated."

4. The extent of the originator's continuing obligation to the SPV after the transfer of assets.

When an originator assigns its accounts receivable to an SPV, there is a legal question as to the extent that the originator may remain involved with the accounts. On one view, if the originator has truly "sold" its accounts, it should have little or no further involvement with them. Once the originator has received the purchase price, it

111 Id at $281-83$.

112829 F2d 705 (9th Cir 1987).

113 Id at 709-11.

114 See Lupica, 76 Tex L Rev at 639-40 n 235 (cited in note 1) (listing factors courts have identified as relevant when determining whether a transaction is a true sale or a secured loan).

115 Evergreen Valley, 23 Bankr at 661. 
should have little interest in whether the accounts are actually collected, since only the buyer should bear the uncollectability losses.

Two cases support this view. In Petron Trading Co v Hydrocarbon Trading \& Transport $\mathrm{Co},{ }^{116}$ the court declined to uphold a true sale when an assignor continued to prepare invoices for contract payments, did not notify its account debtor that its debt had been assigned, and retained rights under the assignment contract to petition the account debtor for price adjustments." Similarly, in In re Major Funding Corp ${ }^{118}$ the court characterized a transaction where the assignor collected mortgage receivables and then paid the proceeds out to its investors/assignees as a secured lending arrangement rather than a true sale. ${ }^{119}$ The court focused on the fact that the assignor did not segregate specific receivables to pay its investors, but rather paid each investor a specified return from its general pool of mortgage receivables. ${ }^{120}$ The return amount was not linked to the collectability of any particular mortgage or mortgages, but was instead a guaranteed fixed amount paid out from the general pool. Notably though, while holding against the assignor, the Major Funding court did not object to the assignor acting as collection agent for the assignees.

Complementing these two cases is the view that if an originator acts as a mere collection agent and processor for the SPV, and nothing more, then a true sale may still exist. The Reform Act is consistent with this view. ${ }^{121}$ This view accounts for the fact that the originator has a closer relationship to its account debtors than does the SPV. It is more efficient for the SPV to hire the originator as its collection and administration agent than to collect and administer the accounts by itself.

Golden Plan supports this view. ${ }^{122}$ The case involved a transaction very similar to a securitization. A mortgage loan company assigned its mortgage loans to a subsidiary, which in turn assigned them to investors. ${ }^{123}$ As part of the assignment agreement, the investors signed a form contract, drawn up by the mortgage lender, that named a collection agent. The collection agent's duties were (1) to collect monthly payments from the mortgage borrower, (2) to forward the payments

\footnotetext{
116663 F Supp 1153 (E D Pa 1986).

117 Id at 1159 .

11882 Bankr 443 (Bankr S D Tex 1987).

119 Id at 449 .

120 Id at 448 .

121 See HR $833 \S 903(\mathrm{e})(5)(B)$ (cited in note 69); $\mathrm{S} 625 \S 903$ (e)(5)(B) (cited in note 69).

122 See 829 F2d at 709.

123 This structure differs from the securitization transaction discussed in this Comment because instead of having the subsidiary sell securities backed by its assets, it sold the assets di-
} rectly. 
to the investor, and (3) to handle any paperwork needed if a mortgage was foreclosed. ${ }^{124}$

The court stated that "[s]uch loan collection agreements suggest that the ... investors, rather than [the mortgage lender or the collection agent], actually owned the note." ${ }^{125}$ On the court's theory, if the investors did not own the mortgage loan receivables, they would not have contracted for their collection. Instead, the mortgage loan company would have still owned the receivables and would have had to make its own arrangements for their collection.

The Golden Plan court held that the mortgage lender and collection agent were mere "intermediaries" between the mortgage borrowers and the investors. ${ }^{126}$ The fact that the seller had control over the collection and administration process did not alter the true sale characterization because the court held that the intent of both the mortgage lender and the investors was to execute a true sale, the agreement was clearly marked "WITHOUT RECOURSE," there was in fact no recourse, and the investors bore all the risk of loss. ${ }^{127}$

After Petron Trading, Major Funding, and Golden Plan, the legal landscape, as it relates to the originator's continuing obligation, seems quite clear. $^{128}$ As long as all the other factors that constitute a true sale are satisfied (such as the absence of price adjustment rights, the segregation of assets, proper intent, proper risk bearing, and lack of recourse), then the fact that the originator or its agent merely acts to collect and administer receivables for the SPV should not jeopardize the true sale characterization.

\section{The equitable powers of bankruptcy courts.}

Even if a securitization overcomes all other legal hurdles, there is still the risk that a bankruptcy court will use its equitable powers to consolidate the SPV into the originator. ${ }^{129}$ In Norwest Bank Worthington $v$ Ahlers, ${ }^{130}$ the Supreme Court stated that "whatever equitable powers remain in the bankruptcy courts must and can only be exercised within the confines of the Bankruptcy Code.",31 Section 105(a) of

124 Golden Plan, 829 F2d at 709.

125 Id.

$126 \mathrm{Id}$.

127 Id at 709-10.

128 This probably explains the lack of recent litigation on the issue.

129 The risk is quite small, but it still needs to be addressed.

130485 US 197 (1998).

131 Id at 206. If the Reform Act is passed, Norwest Bank would prevent courts from using their equitable powers to characterize an asset-backed securitization as a secured loan. But, since the Reform Act is silent on the alter ego issue, one can argue that even under the Reform Act bankruptcy courts may still use their equitable powers to consolidate alter ego SPVs into the originator's bankruptcy estate. 
the Bankruptcy Code provides the statutory authority that grants bankruptcy courts their equitable powers. The provision states that "[t]he court may issue any order, process, or judgment that is necessary or appropriate to carry out the provisions of this title." ${ }^{132}$ This provision applies in all bankruptcy cases.

"A review of the case law reveals that equity has provided the remedy of consolidation in those instances where it has been shown that the possibility of economic prejudice which would result from continued corporate separateness outweighed the minimal prejudice that consolidation would cause. ${ }^{, 133}$ Under this prejudice-balancing test, if the prejudice to the originator's creditors is large, and the corresponding prejudice to the creditors of the SPV-the investors-is small, a bankruptcy court has the power to consolidate the SPV into the originator's bankruptcy estate.

Fortunately for originators, bankruptcy courts have exercised their equitable powers narrowly. ${ }^{135}$ In light of the case law, there must be more than mere prejudice to third party unsecured creditors in order for courts to order equitable consolidation. Only in the extreme case where this prejudice is combined with something like the lack of separate entities ${ }^{136}$ or fraud ${ }^{137}$ will courts be inclined to order this remedy. Nonetheless, practitioners should at least be aware that bankruptcy courts do have equitable powers that could come into play with regard to executory future flow securitizations.

Having described the current state of bankruptcy law as it may pertain to executory future flow securitizations, this Comment now turns to the problems the law presents for executory future flow securitizations.

13211 USC $\$ 105(a)$ (1994).

133 In re Snider Bros, Inc, 18 Bankr 230, 234 (Bankr D Mass 1982) (holding that consolidation was not warranted when maintaining separateness would not cause significant harm or prejudice).

134 For a detailed discussion of the effects of securitizations on third party unsecured creditors, see Lupica, 76 Tex L Rev at 616-58 (cited in note 1).

135 See In re Auto-Train Corp, Inc, 810 F2d 270, 277-78 (DC Cir 1987) (refusing to consolidate a subsidiary's assets into its parent's bankruptcy estate on the ground that the subsidiary's creditors faced detrimental reliance). See also In re DRW Property Co, 54 Bankr 489, 495-97 (Bankr N D Tex 1985) (endorsing the prejudice-balancing test mentioned above in denying a consolidation request and stating that the detriment to the creditors of a subsidiary would outweigh the benefit of consolidation to the parent's unsecured creditors).

136 See Lupica, 76 Tex L Rev at 645 (cited in note 1).

137 See id at 647-48. 


\section{THE DIFFICULTY IN STRUCTURING EXECUTORY FUTURE FLOW SECURITIZATIONS AS TRUE SALES}

In discussing the difficulties with structuring an executory future flow securitization as a true sale, this Comment will revisit the oil company example set out in the introduction. The oil company will have to overcome the following legal hurdles, derived from the case law described in Part II.B, in order for courts to enforce this transaction as a bankruptcy-remote true sale: (1) compensating investors for the extra risk associated with executory future flows without offering recourse; (2) minimizing the originator's continuing obligation; (3) dealing with a sale or merger of the originator; and (4) dealing with bankruptcy courts' equitable powers.

\section{A. The Need to Compensate Investors for the Extra Risk}

Future flow securitizations add an extra layer of potential risk to the investor that is not present in a regular asset-backed securitization. This is the risk that future flows will not occur at the level promised by the debtor, or in extreme cases, that the flows will not occur at all. In the oil company example, this risk includes the possibility that the oil field will not produce as much oil as the engineers expect or that the field might even be dry, the possibility that oil prices will drop, making the cash flow from the field smaller than the expected $\$ 50$ million, and the possibility that new environmental laws will raise costs or restrict pumping.

To attest to investors that these risks are not too great, an SPV must obtain an investment credit rating on the securitized future flows. The credit rating assures investors of the high likelihood that the executory future flows will occur at their predicted rate and quantity. ${ }^{133}$ There is a caveat to the credit rating. "[A] credit rating .... assesses a likelihood of payment on financial obligations [but] does not necessarily reflect the probability of continued production." As a result, investors in the future flow securitization will demand assurances that the oil company will continue to produce oil as expected. In the past, these assurances have taken the form of either straight recourse or overcollateralization. ${ }^{140}$

Straight recourse can be a company-backed cash guarantee that the $\$ 50$ million inflows will be realized, or a promise by the company to indemnify the investors if their predictions about the field were wrong. Since there is recourse against the originator, the SPV and its

138 See Gugliada, 781 PLI/Comm at 611 (cited in note 15).

139 Id.

140 See id at 612-13 (describing the methods used in a future flow securitization to overcome risks within an industry). 
investors do not bear the risk of loss associated with ownership. Consequently, in such situations courts will characterize the securitization as a secured loan rather than a true sale. ${ }^{1.4}$

Overcollateralization would exist if the SPV sold only $\$ 40$ million worth of securities backed by a right to receive all of the future flows on the $\$ 50$ million field. If the entire field underperformed by $\$ 10$ million, the investors would still get paid in full. Plus, the originator would retain any yield above $\$ 40$ million, so as not to lose money on the deal.

Overcollateralization would be very unlikely to pass the legal test of being a true sale. Clearly the investors do not bear the risks associated with ownership of the field, since all losses on the oil field are borne by the originator (assuming the originator picks an overcollateralization amount well in excess of any foreseeable loss the oil field could incur). Furthermore, the investors do not receive the benefits from owning all the future flows, since the originator retains all flows in excess of $\$ 40$ million. An originator must find some structure in which the extra risks of future flow assets are accommodated without using recourse and without denying the investors the benefits and risks of ownership.

\section{B. The Continuing Obligation of the Originator}

If the oil company were securitizing receivables representing oil already sold, a ceasing of its business activities would have no economic effect on investors in the securitization. The receivables accrued already through the company's past sales activities are not dependent on any future business activities. In an executory future flow securitization, however, investors are dependent on the company continuing to extract and sell oil.

The oil company's continuing obligation presents a difficult bankruptcy law issue not encountered with asset-backed securitizations. Section 541(a)(7) of the Bankruptcy Code states that a debtor's bankruptcy estate includes "[a]ny interest in property that the estate acquires after the commencement of the [bankruptcy] case." ${ }^{, 122}$ If the oil company goes into bankruptcy during the oil harvesting period, this provision comes into play; the oil company will be acquiring oil after the commencement of the bankruptcy case. In order to prevent this oil (and the proceeds thereof) from being included in the bankruptcy estate, and to preserve bankruptcy remoteness, it must be demonstrated

141 See text accompanying notes 99-103.

14211 USC $\$ 541(\mathrm{a})(7)$. Clearly, this provision does not apply to asset-backed securitizations. In an asset-backed securitization, the originator has already acquired a "property interest" in the assets at the time of securitization by the mere fact that it must own the assets in order to sell them in an asset-backed securitization. 
that the oil company's harvesting of oil does not constitute an "interest in property." One must argue that the property interest in the oil yet to be harvested was already property of the SPV by virtue of a sale to the SPV prior to the originator's bankruptcy; the originator, by continuing to harvest the oil, does not obtain a property interest in the oil but merely acts as the analogue of a collection agent. The originator merely "collects" the oil and "administers" the sale of the oil and the transfer of the sale proceeds to the SPV. One must analyze the case law on continuing obligations in order to better inform this argument.

As demonstrated by Golden Plan, a court will allow a true sale when the originator's only continuing obligation is merely to collect and administer receivables. ${ }^{143}$ However, the duty to extract and sell oil for ten years is a much more substantial obligation. During the next ten years the oil company will have to make numerous decisions about price, quantity to be extracted per year, and percentage of its overall resources to devote to the particular oil field. It may be difficult for a court to conclude that the SPV "owns" the future flows when it is the originator that makes all of the decisions as to the quality and quantity of the future flows. Since the SPV stands idly by and collects its money, the SPV seems more like a secured lender than an entity with a true ownership interest. For example, in Petron Trading the court made a secured loan determination because the seller retained the right to alter prices received from its accounts without consulting the buyer. ${ }^{14}$ The reasoning was that the seller had too much control over the sold item to characterize the transaction as a true sale.

Control seems to be the theme that underlies both Golden Plan and Petron Trading. Where the originator acts as a mere agent to pass on the future flows, a true sale is still in order. But where the originator acts to control the quality and quantity of the future flows, courts will likely characterize the transaction as a secured loan.

\section{The Sale or Merger of the Originator}

The risk that the originator will be bought or merged is relevant to future flow securitizations. In a regular asset-backed securitization, the assets sold have already accrued and consequently are independent of any future mergers of the originator. In contrast, executory future flow securitizations are dependent on the future activities of the originator. As a result, transactions involving executory future flows

143 See 829 F2d at 709 (finding a true sale when the originator real estate lender merely served as a collection intermediary after transferring the loans to a group of investors).

144663 F Supp at 1159. 
will have to consider how to treat an originator whose assets are purchased or merged during the life of the transaction.

Using the oil company example again, suppose that Exxon buys substantially all of the assets of the oil company in order to obtain extra drilling machines to extract oil from its more lucrative fields. These extra drilling machines previously were used to extract oil from the securitized field. As part of the deal, Exxon must acquire the securitized field, but since it has more lucrative fields, it intends to hold the securitized field in reserve for the next twenty years.

The legal question is whether Exxon, while not a party to the securitization, must assume the oil company's duties to continue to extract oil from the securitized field, or whether it may use the acquired equipment on other fields and let the securitized field lay fallow. Characterizing it differently, should the SPV, as owner, bear the loss of discontinued drilling due to Exxon's purchase? Or should Exxon be forced to honor the securitization agreement?

\section{The Equitable Powers of Bankruptcy Courts}

Bankruptcy courts may use their equitable powers to characterize a future flow securitization as a secured loan rather than a true sale. As noted above, bankruptcy courts use their equitable powers sparingly, usually in cases of fraud or alter ego. This Comment proposes that there are at least two other scenarios that may cause bankruptcy courts to invoke their equitable powers.

First, they may invoke their powers if the debtor's ability to reorganize may be harmed. For example, consider a situation where the oil company is having trouble obtaining a loan that is necessary for it to successfully reorganize. A bank will only give it a loan if it begins harvesting oil from oil fields other than the securitized field, because the bank wants the oil company to generate cash that is unencumbered by the executory future flow securitization. Unfortunately, the oil company only has enough equipment to harvest from one field at a time. Under this scenario, a bankruptcy court could invoke its Section 105 equitable powers, on the belief that it is against public policy to reorganize a company that has a positive going concern value, and order the oil company to stop harvesting the securitized field.

This equitable scenario is analogous to another situation in bankruptcy. Bankruptcy law allows for a cancellation of a security interest in the debtor's equipment when the debtor must use that equipment to reorganize successfully in bankruptcy. ${ }^{145}$ The creditor would still get

145 See United States $v$ Whiting Pools, Inc, 462 US 198 (1983) (requiring the IRS to return the debtor's equipment, even though the IRS had a property interest in the equipment, because the equipment was necessary for the debtor's reorganized business). 
adequate protection for the equipment, ${ }^{146}$ but would have to wait out the entire bankruptcy process. ${ }^{147}$ The theory behind this law is that the benefit of the debtor's reorganization outweighs the creditor's right to the equipment. Similarly, a bankruptcy court might argue that the benefit of the oil company's reorganization outweighs the harm to the oil company's executory future flow investors of staying their claims. Assuming the investors are treated as secured creditors, they will likely receive adequate protection, but they still must endure the lengthy bankruptcy process.

Second, executory future flow securitizations are a peculiar encumbrance to anyone interested in purchasing the originator. Consider again the case where Exxon wishes to purchase the oil company's assets and put the purchased machinery to other uses. If Exxon is required to assume the oil company's future flow securitization agreement, either it will be forced to put assets to a suboptimal use, or it will choose not to engage in an otherwise profitable purchase of the oil company.

Thus, a bankruptcy court may discharge the continuing obligation of the debtor in the executory future flow securitization in order to facilitate the sale of the debtor as a going concern in bankruptcy. It is uncertain where this discharge leaves the securitization's investors. ${ }^{148}$

\section{A PROPOSED STRUCTURE FOR BANKRUPTCY-REMOTE EXECUTORY FUTURE FLOW SECURITIZATIONS}

This Part proposes possible solutions to the problems posed in Part III. By aggregating these solutions, a loose structure for distinguishing a true sale from a executory future flow securitization can be formed.

\section{A. Compensating for the Extra Risk without Compromising True} Sale Status

The extra uncertainty associated with future flow securitizations decreases their value as compared to asset-backed securitizations. Courts will not allow these risks to be eliminated by recourse while still preserving true sale status. Instead of offering recourse, future

146 The creditor will receive an interest in property equal to the value of the equipment. See 11 USC \$ 363(e) (1994) (granting courts the power to protect such interests).

14711 USC \$ 362(a)(3).

148 The securitization investors will likely get some share of the price at which the debtor is purchased. They may even recoup their entire claim. But, in a sense, these investors have already lost; the securitization is no longer bankruptcy-remote since the investors must endure the lengthy bankruptcy proceeding in order to collect on their claims.

149 For example, the ability to receive $\$ 50$ million for certain is worth $\$ 12.5$ million more than a mere 75 percent chance of receiving $\$ 50$ million. 
flow securitizations should account for risks in their price. If risks make future flow securitizations less valuable, originators should simply charge a lower price. Courts likely will uphold this method, since no recourse is present, and the price will be fair.

The problem with this structure is that if the price falls too low, the originator may no longer have an economic advantage from raising capital through securitization. As a result, future flow securitizations will be viable only for those originators who have extremely certain future flows and can therefore still charge a high enough price to make securitization a viable option. These are the originators with investment-grade future flows, such as telephone companies, local municipalities, and natural resource companies, ${ }^{150}$ where the risk of not generating future flows is so slim that they can borrow at investmentgrade interest rates.

\section{B. Solving the Continuing Obligation Problem}

The securitization agreement should explicitly limit the extent to which the originator has "control" over the future flows. The agreement needs to limit the originator's ability to make decisions about price, quantity, and allocation of resources that concern its future flows. The idea is to give bankruptcy courts the sense that the originator is merely a pass-through entity ${ }^{151}$ that must necessarily engage in some administrative tasks, but in no way usurps the SPV's ownership rights.

Using the oil company example again, the best way to prevent the originator from making decisions throughout the life of the securitization is to contract for these decisions ex ante. For example, the securitization agreement can specify that the securitized oil field should account for 10 percent of the originator's total extraction activities per year. It can also state that the oil company must extract and sell a certain amount of oil from the securitized field each year, and that it must immediately sell the oil at the prevailing market rate on the day it is sent to market. Once all variables are contracted for ex ante, the originator looks more like it is merely administering the future flows according to specifications of the securitization agreement.

\section{Accounting for the Sale or Merger of the Originator}

A future flow securitization agreement must provide that the originator will require its acquirer to assume the terms of the securitization upon purchase. This is the only structure in which the SPV in-

150 See Gugliada, 781 PLI/Comm at 611-14 (cited in note 15), for a description of the factors Standard \& Poor's considers in determining a future flow securitization's credit rating.

151 See text accompanying note 47. 
vestors can be assured payment under the securitization. The originator can no longer make payments, since it no longer exists.

\section{Preventing a Bankruptcy Court's Use of Its Equitable Powers}

Courts may exercise their equitable powers in order to ensure the successful reorganization of the debtor. In considering whether to use their equitable powers, courts will use a balancing test to decide whether the benefit of successful reorganization exceeds the harm to the executory future flow investors. It would be very hard to argue that the investors are so severely harmed so as to prevent the successful reorganization of the debtor. The investors are sophisticated, usually insurance companies or other institutional investors, and are therefore probably able to absorb these risks.

$A$ better argument would be for the investors to argue that bankruptcy courts should not interfere with executory future flow securitizations on public policy grounds. The argument would be that all types of securitizations are efficient, and bankruptcy courts should not use their equitable powers to interfere with such efficient transactions.

The academic debate as to whether the securitization transaction in general produces an overall economic efficiency remains unresolved. $^{152}$ Advocates of the efficiency justification state that securitizations offer a cheaper source of borrowing, increased liquidity of assets, better management of the risks associated with receivables, elimination of the need to waste extra assets on collateral, lower monitoring costs for creditors, and a general increase in the availability of credit. ${ }^{133}$ The proposed Bankruptcy Reform Act is evidence that, to some degree, Congress buys this efficiency argument. Detractors of the efficiency justification argue that any efficiency gains of the securitization are offset by the corresponding premium an originator's unsecured creditors will demand in compensation for their heightened risks. ${ }^{154}$ While there is no definitive resolution to this debate, the fact that an originator engages in a future flow securitization demonstrates its belief that the efficiency gains of the securitization outweigh the extra costs it will incur in attracting future unsecured creditors. It is true that the originator's current unsecured creditors will suffer losses. But absent some showing of extreme prejudice, such as fraud, towards these unsecured creditors, courts should honor a properly structured future flow securitization as a true sale.

152 For a general discussion of literature on the efficiency of securitizations, see Lupica, 76 Tex L Rev at 616-31 (cited in note 1).

153 See id.

154 Id at 619-20. 


\section{CONCLUSION}

It remains uncertain whether bankruptcy courts are willing to characterize executory future flow securitizations as bankruptcyremote true sales. What is certain is that the advent of bankruptcyremote executory future flow securitizations would benefit a host of diverse industries. The prototypical company for using executory future flow securitizations is one with expected future cash flows from a presently illiquid asset, a high certainty of realizing these future cash flows, and the need for a large amount of capital as a condition to realizing these future flows. Industries that fit this description include natural resources harvesting, manufacturing of patented drugs, and entertainment copyright royalties. Future flow securitizations will allow these and other industries to grow and prosper by providing a cheaper source of capital and solving liquidity problems. Ultimately, this story of growth and prosperity should persuade bankruptcy courts not to invoke their equitable powers of consolidation. Additionally, a legal structure with a discounted price to investors, no recourse, and as minimal a continuing obligation as can be contracted for ex ante should make it difficult for courts to characterize such transactions as anything but true sales agreements. 


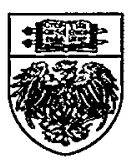

